This item is the archived peer-reviewed author-version of:

Political myth and sacrifice

\title{
Reference:
}

De Vriese Herbert.- Political myth and sacrifice

History of European ideas - ISSN 0191-6599 - 43:7(2017), p. 808-824

Full text (Publisher's DOI): https://doi.org/10.1080/01916599.2017.1321567

To cite this reference: https://hdl.handle.net/10067/1431160151162165141 


\section{POLITICAL MYTH AND SACRIFICE}

\section{Herbert De Vriese}

Philosophy Department

University of Antwerp

Prinsstraat 13 S.D425

2000 Antwerp

Belgium

003232654334

0032468134155

herbert.devriese@uantwerpen.be 


\title{
POLITICAL MYTH AND SACRIFICE
}

\begin{abstract}
This article examines the relationship between political myth and sacrifice. In recent years, as a result of theoretical advances as well as practical concern to understand the rapidly changing landscape of contemporary politics, the phenomenon of political myth has attracted increasing scholarly attention. This has led to a refined and robust theory of political myth, with a sharp analytical edge and relevant practical applications. The relationship between political myth and sacrifice, however, has not been convincingly addressed so far. Gathering insights from the works of Hannah Arendt and Hans Blumenberg, it is argued here that while political myths succeed in providing guidance and orientation to people in a world that is significant to them, they may also involve a loss of sense of reality and produce a dangerous logic of sacrifice.
\end{abstract}

\section{Keywords}

POLITICAL MYTH, SACRIFICE, IDEOLOGY, POLITICAL NARRATIVES, ARENDT, BLUMENBERG

\section{Word count}

8.467 (without footnotes and bibliography) 


\section{POLITICAL MYTH AND SACRIFICE}

\section{Introduction}

In July 1945, just two months after the end of the second World War in Europe, a film production unit of the US Army Air Forces flew over Berlin to document the damage done by years of bombing. ${ }^{1}$ The aerial footage shows a completely devastated city, nearly unfathomable in its scope as the camera slowly moves over Berlin's vast urban landscape from one bombed-out city district to another: an uninterrupted progression of burnt-out buildings, with entire streets reduced to rubble, a labyrinth of free-standing walls rather than coherent structures, revealing no sign of human habitation. Eye-witness accounts state that during the first months after Germany's surrender, the reconstruction of Berlin was deemed impossible: some even assumed that the capital was to remain a somber ruin, perhaps deliberately to be preserved as a gigantic war monument, or to be rebuilt on a new site, miles away from the historic center. ${ }^{2}$ This was the city where only two years before, in his infamous Sportpalast speech, Goebbels had declared the 'total war' and had been met with the overwhelming applause, shouts and choruses of a hysterical audience, asserting its willingness to sacrifice and perseverance.

There is a something uncanny about the defeat of Nazi Germany that resists complete understanding and in my view still poses a problem for political philosophy. How it is possible that an entire people was dragged into this ruinous logic, into this unbending dynamic of destruction? The question tends to provoke other cumbersome questions surrounding the history of Nazi Germany and certainly does not outweigh them, but I would like to focus here on the problem of the sacrifice and self-sacrifice of the German people. ${ }^{3}$ Attempts to present a viable solution to this problem have not failed: analyses of skillful propaganda and indoctrination, of mass hysteria, of totalitarian terror and draconian repression, of the insane cruelty of the leader. Yet time and again political thought is forced to return to the problem, as if realizing that none of the theoretical accounts given, even when combined with one another, can offer a full and satisfactory explanation. Somehow the appalling mystery remains. On the one hand, there is Hitler's firm resolve to bring about the destruction of the German people, literally present in his Testament and unmistakably revealed by his Nero Decree. On the other, one discerns the readiness for self-sacrifice in the German population itself, supported by numerous cases of fanatical resistance and refusal to surrender, even in the face of a war that was already lost. How to make sense of these two destructive tendencies, and how to relate them to each other?

\footnotetext{
1 Cf. "First Motion Picture Unit," Wikipedia, https://en.wikipedia.org/wiki/First_Motion_Picture_Unit and "Special Film Project 186,"Wikiwand, http://www.wikiwand.com/de/Special_Film_Project_186.

${ }^{2}$ See Die Stunde Null: Berlin, Sommer 1945, Spiegel TV, nr. 18, 2008, 60 min.

${ }^{3}$ I do not mean to suggest that the sacrificial logic is something peculiar of Nazism or of the German people as such. If I may refer to other catastrophic battle grounds of World War II, a similar analysis can be given for Stalingrad and Hiroshima.
} 
The willingness for sacrifice, even for self-sacrifice, is not a new phenomenon in the political history of the West. What is new is the massification and radicalization of this sacrificial logic. When considering the situation of the German people during the war, I do not intend to say that every German citizen had become a committed Nazi collaborator or sympathizer, ready to obey the Führer's command at whatever cost. What I wish to emphasize, however, is a mass phenomenon of self-destructive behavior that cannot simply be explained in terms of political manipulation of the population. What is new is a dynamic of self-sacrifice displaying itself at the level of an entire nation, not limited to individuals, specific social groups or military units. Conversely, when turning the attention to the political regime itself, I do not intend to say that by the end of the war all Nazi officials had become convinced that the German people were not worthy to survive and that the German nation should be destroyed. ${ }^{4}$ Yet, making a similar reservation, I do resist the argument that such ideas and plans were entirely due to the evil incarnate in one particular person, or to one absolutely disordered psychology.

In sum, there is something unnatural and blatantly non-commonsensical about the above described tendencies, which defies sound reasoning and traditional models of political thought. It therefore tends to remain a problematic issue, calling time and again for renewed attention and deeper understanding. In The Origins of Totalitarianism, Arendt famously stands out as one of the first political thinkers who have acknowledged the radical newness of political life under Hitler and Stalin. She offers a thoughtful description of the problem:

Supreme disregard for immediate consequences rather than ruthlessness; rootlessness and neglect of national interests rather than nationalism; contempt for utilitarian motives rather than unconsidered pursuit of self-interest; "idealism," i.e., their unwavering faith in an ideological fictitious world, rather than lust for power - these have all introduced into international politics a new and more disturbing factor than mere aggressiveness would have been able to do. ${ }^{5}$

I am tempted to relate this phrase to another passage of her book, where she points to "the realization that something seems to be involved in modern politics that actually should never be involved in politics as we used to understand it". ${ }^{6}$ My objective in this article is not to present the outlines of a definitive solution to this problem, but to contribute to our continuing need to come to terms with it. More particularly, I will do so by examining the intrinsic relationship between political myth and sacrifice.

\section{Political myth}

The specific approach I have taken to analyze the above-described logic of sacrifice and selfsacrifice in the recent history of modern politics, is defined by the theoretical framework of political myth. This explains why the case of Nazi Germany occupies a central place in my introduction: since the publication of Cassirer's The Myth of the State in 1946, the Nazi myth has served as a paradigmatic case for the theoretical conception and study of political myth. There are obvious reasons for the dominant role played by the Nazi myth. First of all, the

\footnotetext{
${ }^{4}$ Albert Speer, who refused to execute the Führer's Nero Decree, is perhaps the most notorious example.

${ }^{5}$ Hannah Arendt, The Origins of Totalitarianism (New York: Harvest, 1976), 417-18.

${ }^{6}$ Ibid., 443.
} 
conscious construction of a mythical Germanic 'Volksgemeinschaft' has often been identified as a typical feature of the political dynamics of the Nazi regime and its techniques of social control and coordination - a characteristic it shares with Italian fascism. ${ }^{7}$ Second, with Alfred Rosenberg as one of the Nazis' chief ideologues, one cannot ignore the presence of substantial theoretical reflection on political myth, mainly through the influence of German romantic philosophy and its "call for a new mythology", but also as a result of how this romantic heritage was adapted to modern uses and transformed into a genuine theory of political myth. ${ }^{8}$

In recent years, the phenomenon of political myth has attracted increasing scholarly attention. One of the greatest advances in research on the topic is that the concept of political myth has begun to establish itself as a relevant concept of political theory. This has not only happened in the domain of political philosophy, where reflection on political myth has its origin and still finds its most authoritative sources, but in that of political science as well. ${ }^{9} \mathrm{On}$ the path to this achievement, three major obstacles had to be cleared away.

The first obstacle was the ordinary language conception of myth, equating myth with fiction, deceit and error. In line with this conception, the term political myth was easily associated with either the political illusions held by the general public or with false and misleading statements made by politicians. Michael Tager refers to a popular 1977 college textbook on political science, in which the concept of political myth was used to present an overview of popular misconceptions about politics. ${ }^{10}$ During the past decades, much theoretical work has been done to define a more robust concept of political myth, one that deserves consideration as a distinctive kind of political narrative and is no longer saddled with the connotations of being unreal or untrue. In the meantime, the body of literature on the topic has expanded significantly, so as to make it improbable today that a state-of-the-art textbook

\footnotetext{
${ }^{7}$ See Detlef Schmiechen-Ackermann, Hrsg. 'Volksgemeinschaft': Mythos, wirkungsmächtige soziale Verheißung oder soziale Realität im 'Dritten Reich'? (Paderborn: Ferdinand Schöningh, 2012); Martina Steber and Bernhard Gotto, eds. Visions of Community in Nazi Germany (Oxford: Oxford University Press, 2014). The deliberate construction of myth in Italian fascism is literally present in Mussolini's Naples Speech of 24th October 1922: "We have created our myth. The myth is a faith, a passion. It is not necessary for it to be a reality. It is a reality in the sense that it is a stimulus, is hope, is faith, is courage. Our myth is the nation; our myth is the greatness of the nation! And it is to this myth, this greatness, which we want to translate into a real reality, that we subordinate everything else." Omnia Opera di Benito Mussolini. Vol XVIII (Florence: La Fenice, 1951), 453-58. Cited in Cyprian P. Blamires, ed., World Fascism. A Historical Encyclopedia. Vol 1 (Santa Barbara: ABC-CLIO, 2006), 4.

${ }^{8}$ See Philippe Lacoue-Labarthe and Jean-Luc Nancy, “The Nazi Myth," Critical Inquiry 16, no. 2 (1990), esp. 301-303 and 305-309. In spite of their reluctance, the authors cannot avoid presenting Rosenberg as one of the foremost modern theorists of the political power of myth. On a closer analysis, however, Rosenberg appears to be only the latest chapter in a longer story of ideological development. In the genealogical line from German Idealist thought on myth to its transformation into a fascist theory of myth, Johann Jakob Bachofen (1815-1887) and Alfred Baeumler (1887-1968) are significant points of reference. For Bachofen, see Henry Tudor, "The Idealist theory of myth," in Political Myth (London: Macmillan, 1972), 21-25. For Baeumler, see David Pan, "The Politics of Myth in the Nazi Period," in Sacrifice in the Modern World. On the Particularity and Generality of the Nazi Myth (Evanston: Northwestern University Press, 2012), 45-77, esp. 49, 66-68.

${ }^{9}$ Two good examples are: Mark Bevir, ed., Encyclopedia of Political Theory (Thousand Oaks: SAGE Publications, 2010), 915-18; Andrew Heywood, Political Ideologies: An Introduction (Basingstoke: Palgrave Macmillan, 2012), 152. For more works, see the bibliography of this article.

${ }^{10}$ Michael Tager, "Myth and Politics in the Works of Sorel and Barthes," Journal of the History of Ideas 47, no. 4 (1986): 638-39.
} 
on political science would use the concept of political myth as a way to discuss prevailing political fictions.

The second obstacle was the intrinsic connection to Nazism. Cassirer's The Myth of the State, published posthumously after his sudden death in 1945, is the birthplace of the theoretical concept of political myth. ${ }^{11}$ In Cassirer's usage, the term is strictly reserved for the 'modern political myths' of the twentieth century, which he defines as skillfully fabricated instruments of political propaganda. ${ }^{12}$ These modern political myths, Cassirer explains, should not be confused with mythical conceptions of primitive societies. Whereas the latter are considered to sprout spontaneously from a largely unconscious social activity, the former must be identified as artificial productions, deliberately shaped and deployed by modern politicians, and with the explicit purpose of turning the irresistible 'binding power' of myth into strong and powerful political weapons. ${ }^{13}$ Even more specifically, political myth is described as an instrument to regulate and control the deeds of man, but to be clearly distinguished from methods of political oppression and compulsion, since it does not use physical force but merely the force of imagination to gain control over the people's feelings, judgments, and thoughts. ${ }^{14}$

Yet, however promising Cassirer's approach may seem, its potential for opening up new fields of inquiry in political theory was significantly constrained by his exclusive focus on one specific case study: the 'race-myth' of the Nazi regime. The third and final part of his work, which title was a direct allusion to Rosenberg's 1930 book The Myth of the Twentieth Century, actually broke down into an analysis of the distinctive ideological influences that had been instrumental in shaping the Nazi myth. Another factor thwarting the theoretical fruitfulness of the new concept of political myth was Cassirer's evolutionary view of civilization, according to which the proper condition for myth to flourish was primitive society. As a modern phenomenon, it was interpreted as a relapse into primitive social life, and hence as a setback from the advances made by reason, progress and humanity in

\footnotetext{
${ }^{11}$ While the discovery of the phenomenon of political myth as a distinct subject of theoretical reflection may be situated in the oeuvre of Georges Sorel, Alfred Baeumler or even much earlier in the oeuvre of Spinoza, the very concept of 'political myth' does not appear in their writings, and is also absent in their reception history prior to the publication of Cassirer's Myth of the State. Carl Schmitt, for instance, who dedicated his 1923 article "Die politische Theorie des Mythus" to a presentation of the ideas of Sorel, does not use the concept of political myth. A notable exception in Sorel scholarship is Robert Waelder, who devoted a separate section to Sorel's ideas under the title 'A Theory of Political Myth' in his 1939 book on the psychological aspects of war and peace. Still, Waelder cannot be considered the initiator of the successful introduction of the concept of political myth into political theory. See Carl Schmitt, Positionen und Begriffe im Kampf met Weimar - Genf - Versailles 19231939 (Berlin: Duncker und Humblot, 1994), 9-18; Robert Waelder, Psychological Aspects of War and Peace (Geneva: Geneva Research Centre, 1939), 44 ff.

${ }^{12}$ Ernst Cassirer, The Myth of the State (Hamburg: Felix Meiner, 2007), 277.

${ }^{13}$ Ibid., 273, 274. The distinction between primitive myth and modern myth is made even more emphatically in the Nachlass edition. See Cassirer, Nachgelassene Manuskripte und Texte. Band 9 (Hamburg: Felix Meiner, 2008), 198: "Myth is, therefore, not the product of single individuals; it is the product of a whole nation that springs organically from its past life. Its origin is wrapt in mystery - and it is this mystery that makes myth venerable and irresistible. But our modern political myths show us quite a different face. They are by no means mysterious; - in a sense they are extremely 'rational.' They have been made by individual men and for special purposes; they have been called into existence by conscious methodical efforts. (...) These modern political myths are not veiled in darkness; on the contrary they were manufactured in broad daylight."

${ }^{14}$ Cassirer, The Myth of the State, 281, 284.
} 
civilization. This typical 'Enlightenment view' of myth and the indissoluble bond between political myth and Nazi Germany both had to be subjected to thorough critique and revision, before academic literature could become acquainted with a less pejorative concept of political myth - one that was not confined to totalitarian regimes and not intrinsically inimical to socalled rational and more civilized forms of political organization such as Western liberal democracy.

The third obstacle was neither related to unfavorable everyday connotations of the term myth, nor to the historical burden of the term political myth, but reached to the heart of political theory itself. This obstacle can be identified as a major classic presupposition of political communication research, namely that political discourse is basically a vehicle for conveying ideological content and is therefore bound, both in its theoretical and rhetorical expressions, to take the form of discursive argument. In other words, when viewed through the lens of scholarly analysis, political speech and propaganda generally emerge as a logical or quasi-logical set of propositions, whose major aim is to make or substantiate a convincing ideological argument, or to counter actual or anticipated objections against it. Recent research has moved away from this view. It has focused on narrative as a distinct and characteristic form of political discourse, one that is not reducible to discursive argument. ${ }^{15}$ So, of the two dominant genres of communication, discursivity and narrativity, the latter is swiftly gaining attention in political theory after a long period of undeserved neglect. ${ }^{16}$ Due to this recent surge of interest in the narrative dimension of politics, functions of political speech and propaganda other than argumentative persuasion have received more scrutiny and attention. The recognition of the importance of political myth relates to this more general discovery of the importance of narratives in political discourse. Theorists of political myth claim that a vital aspect of political life is unduly neglected as long as one remains blind for the political effects and purposes of this specific kind of narrative.

The interesting thing is that attention to political myth is not merely driven by a concern for theoretical clarity, but also by the pressing need to understand the rapidly changing landscape of contemporary politics. The theoretical framework of political myth has been used to analyze the political rhetoric of the 'War on Terror'. ${ }^{17}$ In analyzing the

\footnotetext{
${ }^{15}$ Christopher Flood, "Myth and Ideology," in: Thinking Through Myths. Philosophical Perspectives, edited by Kevin Schilbrack (London: Routledge, 2002), 178. For a more detailed elaboration, see Flood, Political Myth. A Theoretical Introduction (New York: Garland, 1996), 115-120. See also Chiara Bottici and Benoît Challand, The Myth of the Clash of Civilizations (London: Routledge, 2010), 24: "ideologies, as the etymology of the term suggests, are 'ideas' cast in the form of the ' $\log o s$ ', of a rational argument, rather than in that of narrative."

16 A good example of this increased interest is the 2014 foundation of the Journal of Narrative Politics at the University of York. John Lanchaster, "Short Cuts," London Review of Books 33, no. 4 (2011), 24, gives a lucid description of how narrative approaches gained a strong foothold in politics: "Everybody in politics now seems to talk about narratives all the time (...). We no longer have debates, we have conflicting narratives." See also Joshua Dienstag, Dancing in Chains: Narrative and Memory in Political Theory (Stanford University Press, 1997); Molly Patterson and Kristen Renwick Monroe, "Narrative in Political Science," Annual Review of Political Science 1 (1998): 315-331; Shaul R. Shenhav, "Political Narratives and Political Reality," International Political Science Review 27, no. 3 (2006): 245-262; Michael Hanne, William D. Crano and Jeffery Scott Mio, eds. Warring with Words: Narrative and Metaphor in Politics (New York: Psychology Press, 2014); Frederick W. Mayer, Narrative Politics: Stories and Collective Action (Oxford: Oxford University Press, 2014).

17 Joanne Esch, "Legitimizing the 'War on Terror': Political Myth in Official-Level Rhetoric," Political Psychology 31, no. 3 (2010): 357-91.
} 
propagation and 'spectacularization' of the idea that a clash between Islam and the West is taking place in the era after $9 / 11$, the theory of political myth has served as the key analytical instrument to account for the success of the political narrative of the 'Clash of Civilizations' and its transformation into a self-fulfilled prophecy. ${ }^{18}$ Likewise, the concept of political myth can be seen to play a central role in critical discourse analyses of the rhetoric of influential contemporary politicians and community leaders. ${ }^{19}$ And in a highly topical study on the reinvention of populist rhetoric in the digital age, the theory of political myth has been put forward in order to help explain the effective recycling of anti-politics rhetoric in our time. ${ }^{20}$ Here, the inspiration is not merely theoretical, but practical as well: it is informed by the pressing need to answer the question how current-day political discourse is shaping our world. Insights and methodologies from theoretical research on political myth appear to be substantially instructive in advancing our knowledge of these new phenomena. And this even more so when they are backed up by comparative analyses with well-known case studies of modern political myths, such as the American myth of the Founding Fathers, the socialist myth of the General Strike and the Nazi myth of the Aryan Superrace.

\section{Refining the concept}

On the theoretical side of the question, Chiara Bottici has made two major contributions to a better understanding of political myth. First, she has developed an original conception of political myth that moves beyond the true/false dichotomy. Second, she has successfully reconfigured the conceptual framework of political myth by incorporating seminal ideas and insights from Hans Blumenberg's theory of myth. Both contributions result in a much more refined and robust theory of political myth, with a sharp analytical edge and relevant practical applications.

Earlier theorists of political myth had operated within the discursive model of truth claims. Henry Tudor, for example, holds that the significance of political myths does not result from the amount of truth they contain, but from the very fact that they are believed to be true. ${ }^{21}$ In other words, while on the analytical level a political myth was exposed as a kind of irrational, illusionary or otherwise distorted political idea, in practice it was recognized as having a strong connection to truth, by virtue of an existing popular belief that it offered a true account of reality:

Its success as a practical argument depends on its being accepted as true, and it is generally accepted as true if it explains the experience of those to whom it is addressed and justifies the practical purposes they have in mind. ${ }^{22}$

\footnotetext{
${ }^{18}$ Chiara Bottici and Benoît Challand, "Rethinking Political Myth: The Clash of Civilisations as a Self-Fulfilling Prophecy," European Journal of Social Theory 9, no. 3 (2006): 315-36; Bottici and Challand, The Myth of the Clash of Civilizations, esp. 106-110.

19 Jonathan Charteris-Black, Politicians and Rhetoric. The Persuasive Power of Metaphor (Houndmills, Basingstoke: Palgrave Macmillan, 2005), esp. Ch. 8.

${ }^{20}$ Mark Rolfe, The Reinvention of Populist Rhetoric in the Digital Age. Insiders \& Outsiders in Democratic Politics (Singapore: Palgrave Macmillan, 2016), esp. $38 \mathrm{ff}$.

${ }^{21}$ Tudor, Political Myth, 17. See also 133: "A myth may well be believed to be true by those among whom it circulates; but this does not prevent it from being, in actual fact, a set of extravagant illusions."

${ }^{22}$ Tudor, Political Myth, 138.
} 
Christopher Flood, too, in spite of his critique of Tudor's 'psychological' approach to myth and in spite of his support for a functional definition, ${ }^{23}$ refuses the exclusion of the truth versus falsehood dichotomy from the core definition of political myth. His main arguments are, first, that such an operation is counter-intuitive, because "the issue of truth versus falsehood is the essential feature of everyday usage of the word myth", and second, that it conflicts with the various ideological functions of political myth, such as legitimation, political acculturation and mobilization, none of which can adequately be explained without reference to a social group which accepts the narrative as fundamentally true. ${ }^{24}$ In his working definition, Flood presents a political myth as:

an ideologically marked narrative which purports to give a true account of a set of past, present, or predicted political events and which is accepted as valid in its essentials by a social group. ${ }^{25}$

So, basically, this is a different manifestation of the same approach to political myths in terms of their claim to truth.

A short interlude will suffice to show why this approach is problematic. I refer to a peculiar aspect of the paradigmatic case study of modern political myths, the Nazi myth. In the opening chapter of The Myth of the 20th Century, Rosenberg gives a new twist to the myth of Atlantis. He advances the idea that Atlantis, before it disappeared beneath the sea, was a landmass north of Scandinavia, at a time when a much milder climate prevailed in the Arctic. He depicts Atlantis not as a small island, but as a "flourishing continent" of which today only fragments, from Greenland to Novaya Zemlya, still rise above sea level. It is on this prehistoric homeland of the Nordic race, Rosenberg imagines, "over which now the Atlantic waves roll and giant icebergs float," that the Aryan culture was created, and it is from this continent that swarms of warriors and seafarers spread civilization all over the world. ${ }^{26}$ Without a doubt, the story sparks the imagination. And if we relate it to a German audience that is told to be the purest heir of this Nordic master race, it is not an innocent story at that, but one capable of inciting loathsome forms of political action. But let me ask one crucial question: how many Germans would actually have believed that this was a true historical account $?^{27}$ Making the impact of the narrative and its political motive power dependent on the claim that it needs to be accepted by an identifiable social group as fundamentally true, may well mean missing the point of what is actually at stake in the reception of a political myth. It must at once be added, however, that the opposite answer appears to be as unsatisfactory. Stating that the story is pure fiction does not bring much clarity to the problem neither. One should rather conclude that Rosenberg's version of the Atlantis myth, in its vital function as part of the more comprehensive Nazi myth, opens up a dimension beyond the dichotomy of truth and falsehood: while one cannot say that the narrative is believed to be true, neither can

\footnotetext{
${ }^{23}$ Flood, Political Myth, 53-56. See also Bottici, A Philosophy of Political Myth (Cambridge: Cambridge University Press, 2010), 194.

${ }^{24}$ Flood, "Myth and Ideology," 184-85. Cf. id., Political Myth, 41: "In general, political myths do not have sacred status in secular societies, but they need to be accepted as fundamentally true by an identifiable group, whatever its size or constituency."

${ }^{25}$ Flood, Political Myth, 44.

${ }^{26}$ Alfred Rosenberg, Der Mythus des 20. Jahrhunderts (München: Hoheneichen Verlag, 1934), $24-25$.

${ }^{27}$ Even Rosenberg himself did not push his readers into that direction, for he literally states in his book that the 'Atlantis hypothesis' may turn out to be untenable. Ibid., p. 24.
} 
one say that it is acknowledged to be incorrect: an unabashed explanation of its falsehood would probably have been met with disapproval and resistance. ${ }^{28}$

Chiara Bottici has moved beyond the dichotomy of truth and falsehood by undertaking a genealogical study of the concept of myth. One of the most interesting conclusions of her investigation is that the view of myth as untruth or unreason is not inherent to the concept, but springs from a new interpretation of a rather recent date, namely one that has emerged at the beginning of the modern era. The view of myth as untrue or irrational speech, Bottici demonstrates, is mainly due to the entirely new paradigm of rationality that arose in the modern period, a paradigm which in turn necessitated a profound reconstruction of the history of logos from classical Greek philosophy onwards. ${ }^{29}$ As a result of this reconstruction, modern philosophical analyses of myth - in particular those of the Enlightenment - were destined to reveal more about the modern concept of rationality than about the nature of myth itself. Against such biased interpretations, Bottici emphasizes that the essential condition for myth to flourish is the possibility of a plurality of truths and realities. And this relativizing attitude in respect of the truth value of mythical and rational worldviews is only her first preparatory step to making a more radical conclusion: any approach to myth in terms of its 'truth' or 'reality' is essentially flawed. ${ }^{30} \mathrm{~A}$ myth is not a theoretical hypothesis about the constitution of the world, Bottici underscores, but a practical tool to provide guidance and orientation in it. $^{31}$

It is at this point that a deep divide arises between Bottici's interpretation of political myth and that of earlier theoretical models. Theorists like Tudor and Flood had remained wedded to a truth paradigm by their unwavering focus on theoretical attitudes of persuasion and belief. Accordingly, their explanation of the persistence and power of political myths centered on the effectual propagation and acceptance of a particular ideological content.

\footnotetext{
${ }^{28}$ David Pan identifies the ambiguous status as the "aesthetic legitimacy" of myth. In his view, the main reason for unsatisfactory accounts in current literature is the dominance of a strictly theoretical approach to political myth, in which it is either reduced to ideology or to a specific function to enforce an ideology. Such a reductive approach, Pan argues, fails to account for the persistence and power of myth in the face of any rationalist attempts to control it. He locates the source of this persistence and power in the aesthetic character of myth. See Pan, Sacrifice in the Modern World, 45-46. While the aesthetic approach of Pan may be interesting and illuminating from an epistemological point of view, in my view it fails to incorporate the unmediated practical quality of political myth, which has been most forcefully expressed by Sorel. In line with this, the cogency of Bottici's conceptual framework must at least partly be explained by its success of drawing together all of these qualities in one coherent whole. See for instance A Philosophy of Political Myth, 179: "the work on political myth unfolds in a dimension, that of the articulation and creation of significance, that escapes any sharp contraposition between cognitive, practical and aesthetical spheres."

${ }^{29}$ An important element of Bottici's genealogical undertaking is the idea that even the passage from mythos to logos is an artificial construction of the modern period: it is not so much aimed at giving an authentic account of the history of classical Greek philosophy, but rather works as a powerful means for the self-identification of Western rationality. See A Philosophy of Political Myth, 25: "The idea of 'the birth' of philosophy has been used to provide Western rationality with an identity." See also 65: "The rise of a scientific view of the world brought with it a new critical stance towards myth. In Galilei's terms, for instance, the universe is a book that is readable because it is written in mathematical language. This is what sets the scientific logos definitively apart from the 'mythical' and 'imaginary',"'

${ }^{30}$ Bottici, A Philosophy of Political Myth, 82, 98.

${ }^{31}$ Bottici's main source of inspiration here is Georges Sorel's treatment of myth. See Sorel, Reflections on Violence, edited by Jeremy Jennings (Cambridge: Cambridge University Press, 2004); Bottici, A Philosophy of Political Myth, 159-64, esp. 160 and 179. Sorel's ideas are discussed in the next section of this article.
} 
Flood, for instance, writes that "political myths (...) must be identified as vehicles of ideological beliefs and as supports for ideological arguments." 32 Bottici, by contrast, points to their practical dimension. In her view, political myths are always a determination to act, tailored to the specific needs of a concrete socio-political environment. For this reason, they need to be attuned to the political experiences and deeds of a social group or society and must always direct or offer guidance to social action in a way that is pertinent, compelling and upto-date. ${ }^{33}$ "They are narratives that prompt people to action," not because they are believed to be true, but "because they answer a need for significance." 34

So, the decisive factor that turns a political narrative into a political myth is the fact that it has significance for a social group or society. ${ }^{35}$ With this line of thought, a notable shift occurs from a predominantly theoretical attitude of belief in a given worldview towards a predominantly practical attitude of finding one's way in the world. But what exactly does the word 'significance' mean? Here is the place where I have to introduce Bottici's second major contribution to the theory of political myth. As already announced, her research has substantially reconfigured the conceptual framework of political myth by incorporating seminal ideas and insights from the German philosopher Hans Blumenberg. In actual fact, she has 'reenergized' the theory of political myth by moving it to the force field of Blumenberg's theory of myth. So here is the answer: significance [Bedeutsamkeit] is Blumenberg's term. The term is at the heart of his exploration of myth in his influential monograph Work on Myth. Taking his peculiar approach into account is certainly an original move: Bottici is the first theorist of political myth who has sensed the political relevance of Blumenberg's work and has presented it as "the ideal platform for a theory of political myth". ${ }^{36}$ But it appears to be more than just an original move, since it is a convincing and highly appropriate one as well. This may be elucidated by a recent discovery that has confirmed Bottici's intuition.

After the publication of Work on Myth in 1979, Blumenberg was not only praised for opening new avenues in German theory of myth, but also vehemently criticized for leaving out an important dimension of myth. How could one write a study of myth, in postwar Germany and in an intellectual climate still dominated by Vergangenheitsbewältigung, without paying attention to the Myth of the Twentieth Century? How could one argue for the rehabilitation of myth while at the same time neglecting its political dimension and more particularly its relation to the social and political calamities of recent history? Was Blumenberg's consistent 'aestheticization' of myth not completely blind to the destructive derailment of modern myths? ${ }^{37}$ In a letter to one of his critics, however, Blumenberg made the surprising statement that he had decided to drop an entire chapter from his book, one that was

\footnotetext{
${ }^{32}$ Flood, Political Myth, 42.

${ }^{33}$ Bottici, A Philosophy of Political Myth, 183. See also 199: "political myths are invitations to act here and now: hic Rhodus, hic saltus."

${ }^{34}$ Bottici, A Philosophy of Political Myth, 183-84.

${ }^{35}$ Bottici, A Philosophy of Political Myth, 185.

${ }^{36}$ Bottici, A Philosophy of Political Myth, 7. See also Angus Nicholls, Myth and the Human Sciences. Hans Blumenberg's Theory of Myth (New York: Routledge, 2015), 188.

${ }^{37}$ See Nicholls, Myth and the Human Sciences, 199-200. Cf. Götz Müller, "Rezension von Arbeit am Mythos," in Hans Blumenberg, Präfiguration: Arbeit am politischen Mythos, Herausgegeben von Angus Nicholls und Felix Heidenreich (Berlin: Suhrkamp, 2014), 78.
} 
specifically devoted to the use of myth in National Socialism and had cost him more effort than most other topics. The reason for this decision, he wrote, was that it "completely and utterly spoiled my taste for the book." 38 In 2012, the Blumenberg scholar Angus Nicholls discovered the missing chapter in the Blumenberg archive. Together with Felix Heidenreich, he published a critical edition of this text entitled Präfiguration: Arbeit am politischen Mythos, including a 63-page epilogue. Nicholls' discovery not only brings to light some of Blumenberg's explicit views on the political nature and the political instrumentalization of myth, but also uncovers the hidden political subtext and tendency of Work on Myth itself. ${ }^{39}$ It shows that the political dimension is not missing in Blumenberg's theory of myth, but was so far, simply, largely ignored.

This recent development in Blumenberg scholarship gives more legitimacy to treating Blumenberg as a political philosopher and interpreting his Work on Myth as a "latently political book". ${ }^{40}$ This is in keeping with what Bottici had undertaken in 2007 by placing the phenomenon of political myth in the heart of Blumenberg's theoretical framework. As a matter of fact, her manoeuver yields at least two fresh ways of approaching the subject. The first is an 'interrelational' approach to political myth. Thereby, a political myth is no longer viewed as a determinate and consistently identifiable object available for further analysis, but approached from the viewpoint of a continual work on myth. ${ }^{41}$ This process of continual reworking is 'interrelational' because it refers to a vivid dynamic of telling-receiving and retelling with no clear distinction between the productive and the receptive side of communication. ${ }^{42}$ The main result of this new approach is that political myths are no longer charged with an inner capacity to 'naturalize' historically contingent beliefs or worldviews and to turn them into matters beyond dispute, but are rather seen as successful 'survivals' in a creative process of selection and modification, namely as those variants which best succeed in providing guidance for social action. Consequently, it is rather the ever-changing sociopolitical context that will define the persistence and 'pregnancy' of a political myth, than the other way around. ${ }^{43}$ The second fresh insight is the view that political myths are narratives

\footnotetext{
${ }^{38}$ Blumenberg, Präfiguration, 62; Nicholls, Myth and the Human Sciences, 203.

${ }^{39}$ Angus Nicholls und Felix Heidenreich, "Editorische Notiz," in Blumenberg, Präfiguration, esp. 103-107.

${ }^{40}$ Nicholls und Heidenreich, "Editorische Notiz," 103. See also Nicholls, "Political Myth in the Blumenberg Nachlass," in Myth and the Human Sciences, 227-49; Felix Heidenreich, "Political aspects in Hans Blumenberg's philosophy," Revista de Filosofia Aurora 27, no. 41 (2015): 523-39, esp. 531.

${ }^{41}$ Bottici, A Philosophy of Political Myth, 99-100.

${ }^{42}$ Bottici, A Philosophy of Political Myth, 100, esp. footnote 2.

${ }^{43}$ Bottici does not delve deeper into the impact of her dynamic and interrelational approach on the theory of political myth, but one specific result needs to be underlined here: the elimination of the unrewarding and even misleading influence of Roland Barthes' theory of myth from the theoretical framework of political myth (for clear cases of such influence, see for instance Tager, "Myth and Politics in the Works of Sorel and Barthes", and Flood, Political Myth, 161-66). Barthes considers myth as a key ideological tool by virtue of its capacity to 'naturalize' institutions, practices, and beliefs and to turn their culturally contingent character into something given, inevitable, and therefore eternally beyond question. Cf. Roland Barthes, Mythologies (New York: Hill and Wang, 2012), 254: "Semiology has taught us that myth has the task of giving a historical intention a natural justification, and making contingency appear eternal." See also 240-41, 255. Blumenberg, by contrast, explains the iconic constancy of myth not as an inherent feature of mythicization, but rather as a necessary result of the process of continual telling and retelling. Cf. Blumenberg, Work on Myth (Cambridge: MIT Press, 1985), 152: "The age of oral communication was a phase of continual and direct feedback regarding the success of literary means." Ibid., 153: "Transmission by word of mouth (...) creates no obligatoriness except what is contained in the outcome of its processes of testing". So, in Blumenberg's account, work on myth is a quasi-Darwinian
} 
that provide not just meaning, but significance. ${ }^{44}$ According to Blumenberg, significance [Bedeutsamkeit], in contrast to meaning, is always particular and subjective: it is related to the individual subject and its finite historical situation. More specifically, it refers to an involvement with constituent parts of the human world that is not chosen, but given, as the effect of culturally mediated forms of attentiveness such as reverence, astonishment, collective memory and conservation. ${ }^{45}$ Significance relates to things and events that possess 'pregnance' for a historically situated subject and simply cannot leave it indifferent. What is significant thereby offers a defense from indifference, in the sense that it helps shape a lifeworld that corresponds to the need of human beings to live in a world that is not indifferent to them. ${ }^{46}$ This second new approach to political myth in terms of its significance may be presented as a 'phenomenological' one, not so much by virtue of a reference to the phenomenological reduction, but rather by virtue of the major influence here of Husserl's ideas concerning the life-world. ${ }^{47}$

Both elements of Blumenberg's theory, significance and work on myth, have found shelter in Bottici's definition of political myth:

a political myth can be defined as the work on a common narrative by which the members of a social group (or society) provide significance to their political experience and deeds. ${ }^{48}$

The distinctive feature of this definition is the prominence given to the practical nature of political myths. For the effort to provide significance is never a purely theoretical, but always a practical endeavor: it is "the great and burdensome effort of the generations," Blumenberg elucidates, to safeguard a human world that is not indifferent or utterly alien, but close and familiar, and this effort is accomplished "with the full right of one who thereby makes life possible for himself." 49 Likewise, the effort to "make significance" of the specifically political conditions of a social group or society must be understood as driven by the practical and even existential need to "ground" those conditions, to give an account of their origin, to protect

process of selection and optimization that favors the 'pregnance' of what is transmitted and hence tends to filter out a consolidated mythical core that is worthy of preservation and memorization. But this core is not present from the beginning, but only at the end of a long period of testing various contents and forms. To the best of my knowledge, I do not think that Blumenberg ever reacted to Barthes' Mythologies (originally published in 1957), but one might suggest that he would regard Barthes as a typical victim of a 'distorted temporal perspective' and would reject his approach for confusing the causes and the consequences of the mythical process. Although Blumenberg's reflections are bound up with an analysis of oral communication in the age of nonliterate prehistory, his insights into a process of selection and optimization may be transposable to, and even remain valid in, the context of modern political myths. A political myth is not a canonical text that must be protected from corruption and misunderstanding, but can justifiably be associated with the constant work on a political narrative that is tested and modified in a specific socio-political setting, so as to be able to provide orientation in the world to a particular society or a particular social group. At any rate, this assumption is the very point of Bottici's interrelational approach to political myths. See Bottici, A Philosophy of Political Myth, 179: "it is in light of the continual change in their present conditions that human beings are impelled to go back to their political narratives, revise them in light of their new needs and exigencies through their reception, or, when this is not possible, dismiss them."

${ }^{44}$ Bottici, A Philosophy of Political Myth, 115.

${ }^{45}$ Blumenberg, Work on Myth, 68.

${ }^{46}$ Blumenberg, Work on Myth, 69. See also Bottici, A Philosophy of Political Myth, 123-24, 130.

${ }^{47}$ Nicholls, Myth and the Human Sciences, esp. 103-108. See also Bottici, A Philosophy of Political Myth, 105.

${ }^{48}$ Bottici, A Philosophy of Political Myth, 14. See also 133, 179, 200.

${ }^{49}$ Blumenberg, Work on Myth, 337. 
them against indifference ${ }^{50}$ For that reason, the work on political myth centers around the creation of a foundational narrative that offers guidance for social and political action and ensures people's orientation in a world that is home to them. This work entails a process that takes place in various kinds of social practices - one will not discover it by rummaging through archives and libraries and examining "pieces of paper". 51

\section{Sacrifice}

In underlining the practical nature of myth, Bottici follows in the footsteps of another important theorist of political myth whom I have only mentioned in passing so far: Georges Sorel. ${ }^{52}$ For as early as 1908 , Sorel had already underlined the practical nature of political myths: he had described them as "expressions of a will to act" and strictly distinguished them from intellectual products such as utopias that were nothing but "descriptions of things". ${ }^{53}$ In contrast to the political impact of such intellectual products, which had the structural weakness of offering a cognitively graspable and therefore in principle always debatable model of society, political myths were considered to be extremely persuasive since they constituted an integral whole of conviction, not divisible into parts, unanalyzable and thus immune to refutation. "A myth cannot be refuted," Sorel explained, "since it is, at bottom, identical to the convictions of a group, being the expression of these convictions in the language of movement". ${ }^{54}$ So, according to Sorel, a political myth was nothing but the expression of the resolute conviction of a social group: it represented the activity, the sentiments and the ideas of a social group as it prepared itself for political action. ${ }^{55}$ In sum, one should not regard it as the vision of a better future, but as a straightforward determination to act.

Sorel's ideas fit well into the theoretical framework of political myth that has been developed so far. But there is another important theme in Sorel that interests me more at this point: his insights into the inner relationship between political myth and sacrifice. I will first expound his views on this subject and then engage in a deeper analysis.

In Reflections on Violence, Sorel blames the political theorists of his time for being unable to account for the great social movements of history, in particular when it comes to explaining the active participation of the people in those movements and their readiness for sacrifice:

The sacrifice of his life made by the soldier of Napoleon in order to have had the honour of taking part in 'eternal' deeds and of living in the glory of France knowing that 'he would always remain a poor man'; the extraordinary virtues shown by the Romans who resigned themselves to an appalling

\footnotetext{
${ }^{50}$ Bottici, A Philosophy of Political Myth, 178. For the specific meaning of 'grounding', see 123-25.

${ }^{51}$ Bottici, A Philosophy of Political Myth, 181. Ibid: "All activities and practices can become vehicles of political myths inasmuch as they can embody a narrative dimension that satisfies the need for significance."

${ }^{52}$ See supra, footnotes 11,28 and 31 .

${ }^{53}$ Sorel, Reflections on violence, 28. Cf. Bottici, A Philosophy of Political Myth, esp. 159-64, 183-4.

${ }^{54}$ Sorel, Reflections on Violence, 29.

${ }^{55}$ Sorel, Reflections on Violence, 28, 29.
} 
inequality and yet who suffered so much to conquer the world; $(\ldots)$ - these are things that the intellectualist philosophy cannot explain. ${ }^{56}$

Other examples that Sorel describes are the belief in glory fostered by the citizen of the Greek republics as well as by the soldier of the anti-Napoleonic wars of liberation; the unshakeable faith demonstrated by ardent Catholics in their struggle against revolutionary traditions; and, most relevant to the central theme of his book, the perseverance and revolutionary zeal displayed by socialists and workers in their war against modern society. ${ }^{57}$ Sorel argues that the secret of all these 'motive forces' - a secret never discovered by 'intellectualist philosophy' - lies in the myths by which they are supported:

men who are participating in great social movements always picture their coming action in the form of images of battle in which their cause is certain to triumph. I propose to give the name of 'myths' to these constructions $(\ldots) .{ }^{58}$

And so it is shown that the belief in glory was supported by heroic myths and that the struggle of ardent Catholics was motivated by the myth of the Church militant. In the context of socialism, "the general strike of the syndicalists and Marx's catastrophic revolution are such myths." ${ }^{59}$ In sum, when people are passionately involved in great historical movements, one must always be able to detect the myth that serves as their motive force. What interests me here, is not the rather limited (and too antagonistic) conception of political myth, but Sorel's ideas on the intrinsic connection with a logic of sacrifice. So my question is: what is it precisely in this narrative of triumph that makes the Greek, the Roman or the soldier of the wars of Liberty willing to sacrifice his own life?

In order to present Sorel's answer to that question, it is useful to refer to yet another example of his book: the cult of self-sacrifice in early Christianity. As may be expected, Sorel attributes the glory of martyrdom in the first Christian generations neither to deeply-held religious ideals nor to dogmatic tenacity, but to the influence of a powerful narrative, namely the "mythology of the Antichrist". ${ }^{60}$ If one is to explain the conviction of the martyr, he argues, one needs to consider the firm belief that people had in the catastrophes described by numerous apocalypses at the end of the first and the beginning of the second century, all of which gave a fearful dramatic character to the persecution of a Christian. ${ }^{61}$ The essential point of his analysis is that persecutions and punishments, instead of being regarded as misfortunes that had befallen an individual, became heroic events of the historically decisive battle against Satan. In a similar vein, Sorel assures that the myth of the general strike will render the conception of socialism more heroic and its historical force more compelling. It is necessary to persuade socialists of the seriousness and sublimity of their work, he writes, for "it is only on this condition that they will be able to bear the innumerable sacrifices imposed on them by

\footnotetext{
${ }^{56}$ Sorel, Reflections on Violence, 22. The citation is a reference to Ernest Renan, Histoire du people d'Israël (Paris: Calmann-Lévy, 1887-93), vol. IV, 191.

${ }^{57}$ Sorel, Reflections on Violence, resp. 27; 20-21 and 24; 28, 31 and 113-119.

${ }^{58}$ Sorel, Reflections on Violence, 20.

${ }^{59}$ Sorel, Reflections on Violence, 20.

${ }^{60}$ Sorel, Reflections on Violence, 181.

${ }^{61}$ Sorel, Reflections on Violence, 180-81.
} 
a propaganda which can produce neither honours, profits nor even immediate intellectual satisfaction."

So, the immersion in a political myth tends to eclipse one's individual interest and even one's instinct for self-preservation. Sorel resorts to a rather crude version of Bergsonian psychology to clarify this mechanism: while people live outside themselves for the greater part of their lives, and are merely acted upon rather than acting autonomously, there are unique moments when they "get back into pure duration," recover possession of themselves and are able to act freely. ${ }^{63}$ Instead of suggesting that at such moments people are dominated by overwhelming emotions, Sorel maintains that they have finally grasped themselves and succeeded in connecting to the movement of their own creative consciousness. "When we act we are creating a completely artificial world (...) composed of movements which depend entirely on us." ${ }^{64}$ Curiously enough, he also claims that this is the exact psychological state that people experience when they are deeply moved by a political myth. The essential idea is that the immersion in myth entails an immediate determination to act, unmediated by cognitive elements and hence completely free and intuitive. This in turn explains why people "who are living in this world of myths" are secure from all refutation. ${ }^{65}$ With respect to the myth of the general strike, he frames the issue as follows:

Ordinary language could not produce these results in any very certain manner; appeal must be made to collections of images which, taken together and through intuition alone, before any considered analyses are made, are capable of evoking the mass of sentiments which correspond to the different manifestations of the war undertaken by socialism against modern society. ${ }^{66}$

In sum, a political myth connects to the movement of creative consciousness and is thereby capable of evoking instinctively all the essential passions of mass movements and social action. $^{67}$

Although the relationship between political myth and sacrifice is clearly and convincingly portrayed in Sorel's work, the explanation remains rather obscure and unsatisfactory. If we turn to other theorists of political myth, we only discover that the issue has not received serious scholarly attention so far. Tudor and Flood do not address the question of sacrifice. Bottici identifies the problem, but does not provide an analysis. ${ }^{68}$

\footnotetext{
${ }^{62}$ Sorel, Reflections on Violence, 130. See also 113. David Ohana, "Georges Sorel and the Rise of Political Myth," History of European Ideas 13, no. 6 (1991): 734, gives a good summary: "Marxist ideology analyses reality; Sorel's myth mobilises the masses. For Sorel, sociology exposes reality while myth tries to change it."

${ }^{63}$ Sorel, Reflections on Violence, 26.

${ }^{64}$ Sorel, Reflections on Violence, 26-7. By the way, this is the context to determine the precise meaning of the expression "the language of movement" in the second quote of Sorel I have given here. See supra.

${ }^{65}$ Sorel, Reflections on Violence, 30.

${ }^{66}$ Sorel, Reflections on Violence, 113.

${ }^{67}$ Sorel, Reflections on Violence, 118.

${ }^{68}$ Bottici, A Philosophy of Political Myth, 160. Scrutinizing the field of contemporary research on political myth, I must admit that I make abstraction here of the peculiar approach of David Pan. The phenomenon of sacrifice figures prominently in Pan's work, but he approaches it as a structure beyond the intrinsic potential of political myths. See Pan, Sacrifice in the Modern World, 67-8: "The ideas of myth and ritual become instead tools for the implementation of a philosophical-political project. (...) This goal links the fascist understanding of ritual and myth to an enlightenment one. The goal of both perspectives is to delegitimate myth as an organizer of social life (...) and to replace it with concepts imposed by a philosophical leader with an instrumentalist approach." (italics mine)
} 
Cassirer explicitly tackles the issue and develops an explanation, but his solution to the problem, akin to that of Sorel, has the limitation of taking recourse to rather impenetrable psychological mechanisms. Cassirer claims that especially in times of severe and dangerous social crises, individual freedom and responsibility in political life are no longer regarded as the privilege of man, but rather as his burden, and that human beings will consequently try to cast off this burden under extremely difficult conditions. ${ }^{69}$ The question, however, why political myths in particular are so extremely successful in helping men to relieve themselves from all personal responsibility, does not receive a satisfactory answer in my view:

Now the modern political myths (...) undertook to change the men, in order to be able to regulate and control their deeds. The political myths acted in the same way as a serpent that tries to paralyze its victims before attacking them. Men fell victims to them without any serious resistance. ${ }^{70}$

Instead of providing a rational explanation, Cassirer seems to exploit exactly those mythical forces which he so manifestly asserts to abhor in modern politics. ${ }^{71}$

My attempt to gain more insight into this matter brings another important political thinker to the fore: Hannah Arendt. This is the primary reason, by the way, why Arendt figures in the introduction of this text: not because she is the 'usual suspect' when it comes to associating a philosopher to the political constellation of Nazi Germany, but because I believe that Arendt, although she does not choose the register of political myth but that of 'ideological fiction', has deeply interesting things to say about the logic of sacrifice and self-sacrifice. More specifically, her most penetrating reflections on this topic belong to the first section of chapter eleven of The Origins of Totalitarianism dedicated to the study of totalitarian propaganda. In this section, Arendt famously relates "the longing for fiction" to the antiutilitarian dimension of life under the yoke of totalitarianism. ${ }^{72}$ On a closer look, her analyses appear to divide themselves into two different arguments.

Arendt's first argument may be termed a 'determinist' argument. It starts from a characterization of the modern masses, "who had lost their home in the world and now were prepared to be reintegrated into eternal, all-dominating forces" ${ }^{73}$ The condition of homelessness that Arendt depicts here, is the loss of stable social and political bodies that in the past had offered the indispensable means of connecting the individual with the group. As a consequence of the unprecedented alienation and radical loneliness produced by modern civilization, and more specifically as a result of the internal disintegration of the nation-state and its political organization in Europe after the First World War, with a constantly growing

\footnotetext{
${ }^{69}$ Cassirer, Myth of the State, 282-83. Again, the Nachlass edition proves to be a significant source to examine Cassirer's precise views on political myth, for it delves deeper into the issue of sacrifice, both in the modern world and in the context of "the sacrificial rites of the old mythological gods". See Cassirer, Nachgelassene Manuskripte und Texte. Band 9, 212: "Without the reinstatement and the solemn enthronement of mythical thought man would never have acquiesced in these frightful and revolting sacrifices." Nevertheless, this source too lacks a convincing explanation.

${ }^{70}$ Cassirer, The Myth of the State, 281.

${ }^{71}$ I am indebted here to a stimulating observation of Sebastian Müngersdorff's working paper "Blumenberg's aesthetic Umwege to Politics", presented at the Summer school in philosophy and society: Political Myth, Propaganda, and the Politics of Imagination, 29 August 2016.

${ }^{72}$ Arendt, The Origins of Totalitarianism, 352. See also 347-48.

${ }^{73}$ Arendt, The Origins of Totalitarianism, 350.
} 
movement of stateless people and with the transformation of a class-structured society into a mass society of uprooted individuals, ${ }^{74}$ people had literally lost their place in the world and the sense of identity that corresponded with it. The chief characteristic of the modern masses, Arendt summarizes, is that they present "a veritable chaos of individual interests". ${ }^{75}$ In view of that, she attributes the success of totalitarian propaganda to the fact that interest as a collective force has disappeared from the social scene and that political leaders can henceforth afford themselves the luxury of a complete and shocking indifference to mass interest. The upshot of her argument is that the anti-utilitarian behavior of totalitarian governments, which cynically pulls its population towards a fictitious world where it ultimately will have to act against its own interests, is merely a logical reaction to, or even a simple reflection of, the anti-utilitarian mentality that had already taken root in mass society. In sum, it is the uprootedness of the masses in the modern age that explains why they have so dangerously and even fatally drifted away from a concern with self-interest. ${ }^{76}$

The fanaticism of members of totalitarian movements, so clearly different in quality from the greatest loyalty of members of ordinary parties, is produced by the lack of self-interest of masses who are quite prepared to sacrifice themselves. The Nazis proved that one can lead a whole people into war with the slogan 'or else we shall go down' (...). The same spirit showed itself during the last months of a war that was obviously lost, when Nazi propaganda consoled an already badly frightened population with the promise that the Fuehrer 'in his wisdom had prepared an easy death for the German people by gassing them in case of defeat. ${ }^{, 77}$

All of this demonstrates, Arendt argues, "how little the masses were driven by the famous instinct of self-preservation."78 In their typical situation of "spiritual and social homelessness", ${ }^{79}$ they were doomed to become the submissive victims of a regime and propaganda system that would simply instrumentalize their readiness for sacrifice. There is no free choice, no ethical freedom here. According to Arendt, this is just the unavoidable fate of the modern mass individual.

But there is another argument in the same chapter, one that does unfold a dimension of ethical freedom and of existential as well as political commitment. This second argument, which I will term the 'indeterminist' argument, is not only subtler and more profoundly elaborated, but, in my view, more interesting and more convincing as well. Let us take a closer look.

\footnotetext{
${ }^{74}$ See Arendt, The Origins of Totalitarianism, Chapters 9 and 10. A lucid formulation of the problem with respect to the stateless people in Europe is found on p. 293: "The first loss which the rightless suffered was the loss of their homes, and this meant the loss of the entire social texture into which they were born and in which they established for themselves a distinct place in the world. This calamity is far from unprecedented (...). What is unprecedented is not the loss of a home but the impossibility of finding a new one."

${ }^{75}$ Arendt, The Origins of Totalitarianism, 348.

${ }^{76}$ Arendt, The Origins of Totalitarianism, 347-48.

${ }^{77}$ Arendt, The Origins of Totalitarianism, 348. See also 363: "Without the force of the movement, its members cease at once to believe in the dogma for which they yesterday were ready to sacrifice their lives. The moment (...) the fictitious world which sheltered them, is destroyed, the masses revert to their old status of isolated individuals who either happily accept a new function in a changed world or sink back into their old desperate superfluousness."

${ }^{78}$ Arendt, The Origins of Totalitarianism, 348.

${ }^{79}$ Arendt, The Origins of Totalitarianism, 352.
} 
In explaining the effectiveness of totalitarian propaganda, Arendt digs deeper into the characteristic mindset of the modern mass individual. She remarks that this individual is not likely to be convinced by facts, not even by invented facts, but only by the consistency of a system of which he is presumably part. He is more inclined to trust his imaginations, she writes, than the reality of his own experience. ${ }^{80}$ And she adds a clue for this peculiar attraction of the imagination for the uprooted mass man: the imagination it easily caught by what is universal and consistent in itself. ${ }^{81}$ For that reason, the imagination is able to provide a viable substitute for the consistency of sheltering social bonds irrevocably lost in reality. Or, to put it more pointedly, the resort to the imaginary world takes the form of protest or even revolt against a reality that degrades, isolates and renders superfluous:

\begin{abstract}
In other words, while it is true that the masses are obsessed by a desire to escape from reality because in their essential homelessness they can no longer bear its accidental, incomprehensible aspects, it is also true that their longing for fiction has some connection with those capacities of the human mind whose structural consistency is superior to mere occurrence. The masses' escape from reality is a verdict against the world in which they are forced to live and in which they cannot exist, since coincidence has become its supreme master (...). The revolt of the masses against 'realism,' common sense, and all 'the plausibilities of the world' (Burke) was the result of their atomization, of their loss of social status along with which they lost the whole sector of communal relationships in whose framework common sense makes sense. (...) Before the alternative of facing the anarchic growth and total arbitrariness of decay or bowing down to the most rigid, fantastically fictitious consistency of an ideology, the masses probably will always choose the latter and be ready to pay for it with individual sacrifices - and this not because they are stupid or wicked, but because in the general disaster this escape grants them a minimum of selfrespect. $^{82}$
\end{abstract}

This is an intricate passage of which every step of the argument deserves attention. There is no question here, as in Cassirer's account, of blinding or paralyzing, let alone of violent indoctrination. Moreover, also the supposition of an intuitive and perhaps rather naïve surrender to a tantalizing temptation, an interpretation that would come close to Sorel's view, misses the point. Arendt portrays the escape in the imagination as a deliberate choice that is weighed against its potential devastating consequences, and which presupposes, be it in a conscious or unconscious way, a prior awareness of the dehumanizing aspects of the modern world. As an act of rebellion that is meant to safeguard or at least restore the self-respect of a human being, the escape in a world of fiction becomes an understandable decision, even one that is deeply humane and perhaps admirable. So there is, even at the cost of one's own harm and destruction, a peculiar attraction in ideological fiction, which the modern mass individual, out of respect for his own human condition, deliberately refuses to resist.

\title{
Reading Arendt into Blumenberg
}

Although with noticeably different emphases in the approach taken, the "entirely fictitious world" 83 that Arendt describes, composed of crude lies, absurd travesties of facts, conspiracy theories, political secrets and mysteries, quasi-scientific prophecy and fantastical ideological consistency, can plausibly be incorporated in the general theoretical framework of political

\footnotetext{
${ }^{80}$ Arendt, The Origins of Totalitarianism, 351.

${ }^{81}$ Arendt, The Origins of Totalitarianism, 351.

${ }^{82}$ Arendt, The Origins of Totalitarianism, 352.

${ }^{83}$ Arendt, The Origins of Totalitarianism, 362.
} 
myth. But what is more important than an accurate conception of the object itself, is the question of how the political subject relates to it, or more exactly, the question why the political subject, the individual citizen as well as the collective will of the masses, is inclined to take refuge in the artificial world of the imagination. At this point we should consider whether Arendt's argument of a voluntary escape into the sheltering arms of ideological fiction remains plausible in a wider perspective, both in a more general framework of political narratives and in a broader historical context beyond the specific confines of totalitarianism.

What may be crucial to establishing such an interpretation, is the discovery of a striking structural analogy between the approaches of Arendt and Blumenberg, one that so far has never been observed in the literature on political myth. ${ }^{84}$ For Arendt, the persuasive power of totalitarian propaganda sprouts from the need of a disorientated subject to find a home in the world. Confronted with a reality that offers none and only reminds him of his superfluousness in the world, he is prepared to seek refuge in a fictional world, and eagerly consents to being reintegrated into "all-dominating forces which by themselves would bear man, the swimmer on the waves of adversity, to the shores of safety." 85 But in Blumenberg's interpretation, too, work on myth is always set against a horizon of deeply unsettling disorientation and anxiety. For one of the essential functions of myth, in his account, is precisely to put reality, as far as it is experienced as dreadful or perplexingly indifferent, at a safe distance: it is only by virtue of this 'defiant gesture' that a breathing space for significance will open up. ${ }^{86}$ In other words, the specific activity of work on myth is to create a safe haven for human existence by dispelling the horrors of the unsettling and utterly alien, by forcing them back "to the edge of the world" ${ }^{87}$ Blumenberg identifies this specific activity with the Greek concept of 'apotropaion' - the collective name for various rituals and charms to ward off evil - which literally means 'to drive away'.

Basically, man drives away anxiety by name-giving and telling stories. Myth is a strategy to cope with dread by turning it into something nameable: it has the effect of transforming objectless anxiety into object-directed fear. ${ }^{88} \mathrm{~A}$ good example of such narrative strategy is the head of Medusa, on which Blumenberg comments:

This is a unique paradigm of the 'work on myth', that may have begun with the apotropaion of namegiving. ${ }^{89}$

The clue of Blumenberg's functional approach to myth, however, is that the danger has not been eliminated, but merely averted; that the terror has not been conquered, but merely chased

\footnotetext{
${ }^{84}$ I believe that this structural analogy between the approaches of Arendt and Blumenberg is not a coincidence, but can be followed back to a common source in the thought of Heidegger. To resolve this question would require more in-depth research, which is beyond the scope of this text.

${ }^{85}$ Arendt, The Origins of Totalitarianism, 350.

${ }^{86}$ Blumenberg, Work on Myth, 110: "Significance is the form in which the background of nothing [des Nichts], as that which produces anxiety, has been put at a distance (...). For the need of significance is rooted in the fact that we are conscious of never being definitively exempted from the production of anxiety."

${ }^{87}$ Blumenberg, Work on Myth, 26.

${ }^{88}$ Blumenberg, Work on Myth, 4-6, 25; Nicholls, Myth and the Human Sciences, 102.

${ }^{89}$ Hans Blumenberg, Arbeit am Mythos (Frankfurt am Main: Suhrkamp, 1996), 22 (my translation). Cf. Work on Myth, 15: "This is a unique paradigm of the 'work on myth' that may have begun with the 'apotropaic' [hindering, averting] accomplishment of naming."
} 
away. In other words, myth is not an attempt to 'master' reality, but only to "come to terms with it". ${ }^{90}$ Now what is the relevance of these remarks for our inquiry into political myth? The fundamental point is that a political myth may be defined as a characteristic way to deal with the pressing questions that arise from a specific socio-political condition, namely by pushing them aside, by neutralizing and invalidating their insistence, instead of solving them: "Myth does not need to answer questions," Blumenberg writes, "it makes something up, before the question becomes acute and so that it does not become acute."91

In combination with Arendt's insights, however, such a strategy to cope with a deeply discomforting or even existentially threatening socio-political condition, may also bring with it a complete loss of sense of reality, and even the destruction of common sense. ${ }^{92}$ This is an inherent danger to which Blumenberg is also sensitive, and which he explicitly addresses in the chapter he decided to leave out from Work on Myth. There, he describes Hitler's "eschatological cynicism" with respect to the imminent downfall of the German Reich and shows how deeply it is impregnated by mythical theories of destiny and cosmic fate. ${ }^{93}$

Who knows, when once again a penetration of the moon in the earth takes place and this entire planet could go up in fire and ashes. The imminent downfall appears small and trivial, when it is seen against the background of cosmic inevitability. ${ }^{94}$

In sum, the effort to keep reality at a distance may entail the risk of losing all sense of reality. Work on political myth may involve the inherent danger of closing one's eyes to the everyday realities of life, and this even with stubborn and voluntary tenacity. It goes without saying that such tenacious seclusion from the laws and constants of normal life is vulnerable to giving in to a logic of sacrifice.

\footnotetext{
${ }^{90}$ The subject of the apotropaic function of myth is profoundly elaborated in Nicholls, Myth and the Human Sciences (esp. 108-16, in the section on the anthropological reduction), but is completely absent in Bottici's theory of political myth. An analysis of the function of name-giving, A Philosophy of Political Myth, 120, reads as follows: "As Blumenberg noticed, there is a functional analogy between myth, science and metaphysics: by naming the unknown, they all contribute to its mastery." In Blumenberg's account, however, work on myth is never about mastering the unknown, but about coming to terms with it - and this more precisely by way of averting the unknown, dispelling it, driving it out. Bottici may have been misled here by a wrong translation in Work on Myth, 26, which renders a key passage on the apotropaic function as follows: "Theory is the better adapted mode of mastering the episodic tremenda [terrors] of recurring world events." The original text, however, has 'Bewältigung', not 'Beherrschung', a term that should be translated here by 'coming to terms with'. See Blumenberg, Arbeit am Mythos, 33. Furthermore, the idea of "Beherrschung der Wirklichkeit", often associated with modern science and the sovereign modern subject, is unmasked as an illusion by Blumenberg, as "a dream that has been dreamed out, or was never worth dreaming". Work on Myth, 3. See also p. 9.

${ }^{91}$ Blumenberg, Work on Myth, 197.

${ }_{92}$ Arendt, The Origins of Totalitarianism, 352. See also 457-58.

${ }^{93}$ The specific influence on Hitler that Blumenberg mentions here is the 'World Ice Theory' by Hans Hörbinger. Also in Hans-Jürgen Syberberg's film Hitler. A film from Germany (1977) - a film which Lacoue-Labarthe and Nancy, "The Nazi Myth", 303, describe as impressively instructive for an analysis of the Nazi myth Hörbinger's theory is given a prominent role in evoking the mythical dimension of Nazi ideology, and this at the expense of Rosenberg. See for instance the following passage, spoken in the film by a so-called follower of Hörbinger: "Erinnern wir uns an die großen Gestalten der Vorzeit aus Heldenepen, Träume aus Sagen und Märchen in der Seele unseres Blutes. Wir in uns. Wiedererwachen aus mythischen Kräften. Jeder Mißbrauch schafft seelische Katastrophen von kosmischen Ausmaßen. Die Lehre von unserem Innern heißt nicht Psychologie, sondern Mythos." Transcript in Hans-Jürgen Syberberg, Hitler, ein Film aus Deutschland (Hamburg, Rowohlt, 1978), 167.

94 Blumenberg, Präfiguration: Arbeit am politischen Mythos, 38 (my translation).
} 
By way of conclusion, I would like to mention an observation by Blumenberg that suggests an even stronger connection between political myth and sacrifice. In the first chapter of Work on Myth, Blumenberg proposes that human sacrifice is not only an extreme case of apotropaion, but probably its oldest and most basic form. ${ }^{95}$ This suggestion makes the evilaverting power of myth not only functionally equivalent to the supposed effects of human sacrifice, but integrates both of them in a long history of human civilization, where work on myth appears to be nothing more than the 'domesticated' type of a cruder and primordial practice. It is by telling the story that the gods do not want men as sacrifices, but other gifts such as the sacrifice of animals, that the practice of human sacrifice may be overcome. But even then, Blumenberg ominously remarks, it still preserves the memory of its origin:

\footnotetext{
In connection with the function of institutional renunciation of human sacrifice, the Spartan version of the myth is instructive, according to which Orestes brought the Taurian statue of Artemis to Sparta, where he became king; the idol brought human sacrifice along with it, until the giver of Sparta's constitution, Lycurgus, put an end to it: at the price, however, of still offering to the goddess's thirst for blood at least its smell, by means of the flogging of the Spartan boys. ${ }^{96}$
}

So, in spite of the initial success of mythical substitution, the concern "of falling short of the threshold of divine requirements" 97 may remain, and bring with it a new need for real, physical sacrifices. Seen in a wider perspective, one might conclude that the stories that are told to keep the indifference of the world at a distance and to secure a breathing space for human beings, are provisional successes in the millennial struggle of human civilization for which earlier generations have been prepared to pay with their lives, or with the lives of their fellows. I present this final observation as a sign, or even a 'symbol', of the intrinsic bond between myth and sacrifice, and as a source for further philosophical reflection.

\footnotetext{
${ }^{95}$ Blumenberg, Work on Myth, 6, 19-20.

${ }^{96}$ Blumenberg, Work on Myth, 20.

${ }^{97}$ Blumenberg, Work on Myth, 20.
} 


\section{Bibliography}

"First Motion Picture Unit." Wikipedia.

https://en.wikipedia.org/wiki/First_Motion_Picture_Unit. Accessed $26^{\text {th }}$ Januar 2017.

"Special Film Project 186." Wikiwand.

Arendt, Hannah. The Origins of Totalitarianism. New York: Harvest, 1976.

Barthes, Roland. Mythologies. New York: Hill and Wang, 2012.

Bevir, Mark, ed. Encyclopedia of Political Theory. Thousand Oaks: SAGE Publications, 2010

Blamires, Cyprian P., ed., World Fascism. A Historical Encyclopedia. Vol 1. Santa Barbara: ABC-CLIO, 2006.

Blumenberg, Hans. Arbeit am Mythos. Frankfurt am Main: Suhrkamp, 1996.

Blumenberg, Hans. Präfiguration: Arbeit am politischen Mythos, Herausgegeben von Angus Nicholls und Felix Heidenreich. Berlin: Suhrkamp, 2014.

Blumenberg, Hans. Work on Myth. Translated by Robert M. Wallace. Cambridge: MIT Press, 1985.

Bottici, Chiara and Benoît Challand, "Rethinking Political Myth: The Clash of Civilisations as a Self-Fulfilling Prophecy," European Journal of Social Theory 9, no. 3 (2006): 315-36.

Bottici, Chiara and Benoît Challand, The Myth of the Clash of Civilizations. London: Routledge, 2010.

Bottici, Chiara and Kühner, Angela. "Between Psychoanalysis and Political Philosophy:

Towards a Critical Theory of Political Myth.” Critical Horizons 13, no. 1 (2012): 94112.

Bottici, Chiara. "Philosophies of Political Myth, a Comparative Look Backwards Cassirer, Sorel and Spinoza." European Journal of Political Theory 8, no. 3 (2009): 365-382.

Bottici, Chiara. "Towards a Philosophy of Political Myth.” Iris 3, no. 5 (2011): 31-52.

Bottici, Chiara. A Philosophy of Political Myth. Cambridge: Cambridge University Press, 2010

Brennan, Johnny. "Imagination, Prophecy, and Morality: The Relevance and Limits of Spinoza's Theory of Political Myth." Télos no. 169 (2014): 64-83.

Calvert, John. "Sayyid Qutb and the Power of Political Myth: Insights from Sorel." Historical Reflections 30, no. 3 (2004): 509-28.

Cassirer, Ernst. Nachgelassene Manuskripte und Texte. Band 9. Hamburg: Felix Meiner, 2008.

Cassirer, Ernst. The Myth of the State. Hamburg: Felix Meiner, 2007.

Charteris-Black, Jonathan. Politicians and Rhetoric. The Persuasive Power of Metaphor. Houndmills, Basingstoke: Palgrave Macmillan, 2005.

Die Stunde Null: Berlin, Sommer 1945. Spiegel TV, nr. 18. 2008, 60 min.

Dienstag, Joshua. Dancing in Chains: Narrative and Memory in Political Theory. Stanford University Press, 1997.

Esch, Joanne. "Legitimizing the 'War on Terror': Political Myth in Official-Level Rhetoric," Political Psychology 31, no. 3 (2010): 357-91.

Flood, Christopher. Political Myth. A Theoretical Introduction. New York: Garland, 1996.

Hanne, Michael, William D. Crano and Jeffery Scott Mio, eds. Warring with Words: Narrative and Metaphor in Politics. New York: Psychology Press, 2014.

Heidenreich, Felix. "Political aspects in Hans Blumenberg's philosophy," Revista de Filosofia Aurora 27, no. 41 (2015): 523-39.

Heywood, Andrew. Political Ideologies: An Introduction. Basingstoke: Palgrave Macmillan, 2012 
http://www.wikiwand.com/de/Special_Film_Project_186. Accessed 26 ${ }^{\text {th }}$ Januar 2017.

Kirke, Xander. "Violence and Political Myth: Radicalizing Believers in the Pages of Inspire

Magazine.” International Political Sociology 1, no. 9 (2015): 283-298.

Lacoue-Labarthe, Philippe and Jean-Luc Nancy, "The Nazi Myth," Critical Inquiry 16, no. 2 (1990): 291-312.

Lanchaster, John, "Short Cuts," London Review of Books 33, no. 4 (2011), 24.

Mayer, Frederick W. Narrative Politics: Stories and Collective Action. Oxford: Oxford University Press, 2014.

Mussolini, Benito, Omnia Opera di Benito Mussolini. Vol XVIII. Florence: La Fenice, 1951.

Nicholls, Angus. Myth and the Human Sciences. Hans Blumenberg's Theory of Myth. New York: Routledge, 2015.

Ohana, David. "Georges Sorel and the Rise of Political Myth," History of European Ideas 13, no. 6 (1991): 733-46.

Pan, David. Sacrifice in the Modern World. On the Particularity and Generality of the Nazi Myth. Evanston: Northwestern University Press, 2012.

Patterson, Molly and Kristen Renwick Monroe, "Narrative in Political Science," Annual Review of Political Science 1 (1998): 315-331.

Rolfe, Mark, The Reinvention of Populist Rhetoric in the Digital Age. Insiders \& Outsiders in Democratic Politics. Singapore: Palgrave Macmillan, 2016.

Rosenberg, Alfred. Der Mythus des 20. Jahrhunderts. München: Hoheneichen Verlag, 1934.

Schilbrack, Kevin, ed. Thinking Through Myths. Philosophical Perspectives. London: Routledge, 2002.

Schmiechen-Ackermann, Detlef, Hrsg. 'Volksgemeinschaft': Mythos, wirkungsmächtige soziale Verheißung oder soziale Realität im 'Dritten Reich'? Paderborn: Ferdinand Schöningh, 2012.

Schmitt, Carl. Positionen und Begriffe im Kampf met Weimar-Genf-Versailles 1923-1939. Berlin: Duncker und Humblot, 1994.

Shenhav, Shaul R. "Political Narratives and Political Reality," International Political Science Review 27, no. 3 (2006): 245-262.

Sorel, Georges. Reflections on Violence, edited by Jeremy Jennings. Cambridge: Cambridge University Press, 2004.

Steber, Martina and Bernhard Gotto, eds. Visions of Community in Nazi Germany Oxford: Oxford University Press, 2014.

Syberberg, Hans-Jürgen. Hitler, ein Film aus Deutschland. Hamburg, Rowohlt, 1978.

Tager, Michael. "Myth and Politics in the Works of Sorel and Barthes," Journal of the History of Ideas 47, no. 4 (1986): 625-39.

Tudor, Henry. Political Myth. London: Macmillan, 1972.

Waelder, Robert. Psychological Aspects of War and Peace. Geneva: Geneva Research Centre, 1939. 